\title{
RADIOGRAPHICAL ANALYSIS OF FLEXIBILITY OF IDIOPATIC SCOLIOSIS IN PRONO AND SUPINO
}

\author{
ANÁLISE RADIOGRÁFICA DA FLEXIBILIDADE DA ESCOLIOSE IDIOPÁTICA EM PRONO E SUPINO \\ ANÁLISIS RADIOGRÁFICO DE LA FLEXIBILIDAD DE LA ESCOLIOSIS IDIOPÁTICA EN \\ PRONO Y SUPINO
}

\author{
Marcelo Paulo Melo de Souza, $\mathbb{D}^{1}$ André Flavio Freire Pereira, ${ }^{\mathbb{D}}$ Tulio Albuoueroue de Moura Rangel, ${ }^{\mathbb{D}}$ Rodrigo Castro de Medeiros, \\ luciano Temporal Borges Cabral, ${ }^{1}$ Marcus André Costa Ferreira, ${ }^{1}$ Antonio Reinaldo de Sousa Filmo ${ }^{1}$ \\ 1. Hospital Getúlio Vargas, Department of Orthopedics and Traumatology, Spine Surgery Group, Recife, PE, Brazil.
}

\begin{abstract}
Objective: To determine if there is a statistically significant difference in the flexibility of the curves in the adolescent idiopathic scoliosis (AIS) by using lateral inclination radiographs in supine or prone decubitus. Methods: We evaluated 19 patients with AIS, waiting for surgery. Radiographs of the patients were performed in orthostatic anteroposterior incidences and right and left lateral inclinations in prone and supine decubitus. The comparison between prone and supine decubitus was performed through the flexibility rates of the curves measured in each position. Results: The mean flexibility rates measured in lateral inclination radiographs with the patient in the supine position were $54.4 \% \pm 38.8 \%$ in the proximal thoracic curve, $45.8 \% \pm 15.6 \%$ in the main thoracic curve, and $80.5 \% \pm 20.7 \%$ in the thoracolumbar / lumbar curve. When the lateral inclination radiographs were performed with the patient in the prone position, we observed mean flexibility rates of $66.4 \% \pm 34.3 \%$ in the proximal thoracic curve, $50.1 \% \pm 12.8 \%$ in the main thoracic curve, and $80.6 \% \pm 19.0 \%$ in the thoracolumbar / lumbar curve. Conclusion: This present study did not find a statistically significant difference between the flexibility rates of the curves in the prone and supine positions, suggesting that the two radiographic methods analyzed are similar in the evaluation of the flexibility of the curves in adolescent idiopathic scoliosis. Level of evidence II; Development of diagnostic criteria in consecutive patients (with "gold" reference standard applied).
\end{abstract}

Keywords: Adolescent Idiopathic Scoliosis; Radiography; Flexibility.

\section{RESUMO}

Objetivo: Determinar se há diferença estatisticamente significativa na flexibilidade das curvas na escoliose idiopática do adolescente (EIA), ao utilizar radiografias em inclinação lateral em decúbito supino ou prono. Métodos: Foram avaliados 19 pacientes com EIA, em espera de cirurgia. Os pacientes realizaram radiografias em incidências anteroposterior em ortostase, inclinações laterais direita e esquerda em decúbito prono e supino. Realizou-se a comparação entre o decúbito prono e supino através das taxas de flexibilidade das curvas aferidas em cada posição. Resultados: A taxa de flexibilidade média aferida, quando realizadas as inclinações laterais com o paciente em posição supino, foi de $54,4 \% \pm 38,8 \%$ na curva torácica proximal, $45,8 \% \pm 15,6 \%$ na curva torácica principal e $80,5 \% \pm 20,7 \%$ na curva toracolombar/lombar. Quando realizadas as inclinações laterais com o paciente em posição prono, observou-se taxa de flexibilidade média de 66,4\% \pm 34,3\% na curva torácica proximal, 50,1\% $\pm 12,8 \%$ na curva torácica principal e 80,6\% $\pm 19,0 \%$ na curva toracolombar/lombar. Conclusão: O presente estudo não encontrou diferença com significância estatística nas taxas de flexibilidade das curvas nas posições prono e supino, sugerindo que os dois métodos radiográficos analisados são semelhantes na avaliação da flexibilidade das cunvas na escoliose idiopática do adolescente. Nível de evidência II; Desenvolvimento de critérios diagnósticos em pacientes consecutivos (com padrão de referência "ouro" aplicado).

Descritores: Escoliose Idiopática do Adolescente; Radiografia; Flexibilidade.

\section{RESUMEN}

Objetivo: Determinar si hay diferencia estadísticamente significativa en la flexibilidad de las curvas en la escoliosis idiopática del adolescente (EIA), al utilizar radiografías en inclinación lateral en decúbito supino o prono. Métodos: Se evaluaron 19 pacientes con EIA, en espera de cirugía. Los pacientes realizaron radiografías en incidencias anteroposterior en ortostasis, inclinaciones laterales derecha e izquierda en decúbito prono y supino. Se realizó la comparación entre el decúbito prono y supino a través de las tasas de flexibilidad de las curvas medidas en cada posición. Resultados: La tasa de flexibilidad promedio medida, cuando se realizaron las inclinaciones laterales con el paciente en posición supino, fue de 54,4\% $\pm 38,8 \%$ en la curva torácica proximal, $45,8 \% \pm 15,6 \%$ en la curva torácica principal, y $80,5 \% \pm 20,7 \%$ en la curva toracolumbar/lumbar. Cuando se realizaron las inclinaciones laterales con el paciente en posición prono, se observó tasa de flexibilidad promedio de 66,4\% \pm 34,3\% en la curva torácica proximal, $50,1 \% \pm 12,8 \%$ en la curva torácica principal, y 80,6\% $\pm 19,0 \%$ en la curva toracolumbar/lumbar. Conclusión: El presente estudio no encontró diferencia con significancia estadística en las tasas de flexibilidad de las curvas en las posiciones prono y supino, sugiriendo que los dos métodos radiográficos analizados son semejantes en la evaluación de la flexibilidad de las curvas en la escoliosis idiopática del adolescente. Nivel de evidencia II; Desarrollo de criterios diagnósticos en pacientes consecutivos (con el estándar de referencia "oro" aplicado).

Descriptores: Escoliosis Idiopática del Adolescente; Radiografía; Flexibilidad. 


\section{INTRODUCTION}

Defined as a three-dimensional spinal deformity (involving the sagittal, transverse, and frontal planes), ${ }^{1}$ scoliosis affects around 2-3\% of children. ${ }^{2}$ Its treatment is divided into non-surgical and surgical. ${ }^{3,4}$ Observation, with serial imaging examinations is used in cases where the Cobb angle $<20^{\circ}$. In cases of patients with skeletal immaturity (Risser 0,1 , or 2 ) with curves between $20-40^{\circ}$ the use of orthotics is recommended. ${ }^{3-5}$ Surgical approach is another form of treatment. The indication and planning of surgical treatment involve a detailed analysis of the characteristics of the curves, especially of their magnitude and flexibility, in addition to coronal and sagittal balance. ${ }^{6}$ Its classic indication involves cases of curves with Cobb angles $>40-45^{\circ} .1,3-5$

Preoperative surgical planning is of fundamental importance to prevent complications and poor results in any procedure, especially in surgical cases of adolescent idiopathic scoliosis (AIS). Correct operative planning in AIS allows the preservation of mobile segments and reduces surgical time and blood loss., ${ }^{7,8}$ In order to improve indications and surgical planning, several classification systems for adolescent idiopathic scoliosis were proposed. In 1983, King et al. proposed a classification system based on the evaluation of coronal radiographs, dividing the scoliotic curves into five types. ${ }^{9}$ In 2001 , Lenke et al. structured the currently most commonly used classification based on the concept of three-dimensional deformity. In it, cases of scoliosis are evaluated in the coronal and sagittal planes and the flexibility of the curves is measured and recorded. ${ }^{10}$ Based on this classification, the assessment of the flexibility of the curves in scoliosis has been shown to be fundamental to the characterization of the deformity, assisting in the preoperative planning of patients and in defining the levels to be involved in arthrodesis and the correction to be achieved. ${ }^{11}$ Several forms of flexibility assessment have been proposed and compared, however there is still no consensus in the literature around which one should be used. .,11 $^{1}$

Given that the usual surgical positioning of patients with scoliosis is ventral decubitus, the use of radiographic images in the prone position is reasonable in preoperative planning. Using radiographs in the supine position would simulate intraoperative positioning and could provide the surgeon with more relevant information.

This study aimed to determine whether there is a statistically significant difference in the flexibility of curves in adolescent idiopathic scoliosis when using lateral inclination radiographs in supine or prone positions.

\section{METHODS}

A cross-sectional study was conducted with patients diagnosed with adolescent idiopathic scoliosis waiting for surgery.

The sample was composed of patients who were on a waiting list for surgical treatment of adolescent idiopathic scoliosis, treated and in follow-up at the outpatient spine clinic of the orthopedics and traumatology department of a tertiary hospital that serves the Unified Health System.

The patients were invited to participate in the study during the reregistration and updating of their data on the waiting list for surgical treatment, performed in April 2019.

The inclusion criteria used were:

1. Adolescent idiopathic scoliosis diagnosis

2. On the waiting list for surgery

3. Having signed the ICF

4. Female patients

The study exclusion criteria were:

1. Those who did not want to participate or did not sign the ICF

2. Case of scoliosis with other etiologies

3. Male patients

The exclusion of male patients was aimed at making the sample more homogeneous in order to make the results more reliable.

The patients underwent anamnesis and physical examination. The anamnesis evaluated data on sex, patient age, age at menarche, age at AIS diagnosis, family history of AIS, and treatment with physical therapy and orthotics. With the patient in orthostasis, the physical examination assessed shoulder leveling and trunk balance.

Panoramic spinal radiographic images were taken under the supervision of the medical examiner in the following incidences:

1. Anteroposterior in orthostasis

2. Lateral in orthostasis

3. Right and left lateral inclinations in the prone position

a. With the patient in dorsal decubitus on the radiotransparent table

b. Pelvis balanced and level with the horizontal line of reference

c. Upper limbs turned to the side of the inclination

d. Maximum active inclination allowed before the pelvis leaves its primary leveling

4. Right and left lateral inclination in the supine position:

a. Pelvis balanced and level with the reference line

b. Face turned to the side of the inclination

c. Upper limbs turned to the side of the inclination

d. Maximum active inclination allowed before the pelvis leaves its primary leveling

The Cobb angles of the curves were measured and defined in each of the radiographs by consensus of 3 spine surgeons with more than 10 years of experience, and the Lenke classification was determined from the right and left lateral inclination radiographs in both prone and supine positions.

The flexibility rates of the proximal thoracic, main thoracic, and thoracolumbar/lumbar curves were also evaluated in the supine and prone inclinations using the formulas:

- Flexibility rate in the prone position $(\%)=($ Cobb angle value in the AP - Cobb angle value in the PRONE inclination) / Cobb angle value in the AP $\times 100$

- Flexibility rate in the supine position $(\%)=(\mathrm{Cobb}$ angle value in the AP - Cobb angle value in the SUPINE inclination) / Cobb angle value in the AP $\times 100$

Statistical analysis was performed using SPSS 13.0 (Statistical Package for the Social Sciences) for Windows and Excel 2010. All the tests were applied with 95\% confidence. The results are presented in table form with their respective absolute and relative frequencies. The numeric variables are represented by central tendency measures and measures of dispersion. The comparison with two groups was conducted with the Mann-Whitney test (Not Normal). We used the Wilcoxon (Not Normal) test for the test between paired groups. Spearman's correlation coefficient was used to verify correlation between variables.

The individuals who met the inclusion criteria and accepted participation in the study were made aware of the scientific use of the research and the risks and signed the Informed Consent Form, in addition to the consent form for research in subjects under 18 years of age. The scientific project was submitted to the Institutional Review Board and followed the Guidelines and Regulatory Standards for research involving human beings established by National Health Council Resolution 466/12 of December of 2012.

\section{RESULTS}

Nineteen patients, all of them female, diagnosed with adolescent idiopathic scoliosis and on the surgery waiting list were evaluated. The mean age of the patients analyzed was $14.3 \pm 2.2$ years and the mean age at AIS diagnosis was $11.9 \pm 1.3$ years. (Table 1 )

The evaluation of radiographic aspects showed that all patients had a left proximal thoracic curve, a right main thoracic curve, and a left thoracolumbar/lumbar curve. The mean values of the Cobb angle measurements in the anteroposterior incidence radiographs in the orthostatic position were $22.4^{\circ} \pm 12.2^{\circ}$ for the proximal thoracic curve, $55.6^{\circ} \pm 13.1^{\circ}$ for the main thoracic curve, and $40.1^{\circ} \pm 13.1^{\circ}$ for the thoracolumbar/ lumbar curve. The mean degree of thoracic kyphosis, measured from $\mathrm{T} 5$ to $\mathrm{T} 12$ in the lateral radiographs, was $25.9^{\circ} \pm 11.8^{\circ}$. (Table 2 )

The Cobb angle measurements in the right and left lateral inclination radiographs in the supine position were a mean proximal thoracic curve of $20.0^{\circ} \pm 12.2^{\circ}$, a mean main thoracic curve of $30.5^{\circ} \pm 12.4^{\circ}$, and a mean thoracolumbar/lumbar curve of $17.1^{\circ} \pm 9.7^{\circ}$. When the 
Table 1. Patient age, age at menarche, and age at AIS diagnosis.

\begin{tabular}{c|c|c|c}
\hline Variables & Mean \pm SD & Median $(\mathbf{Q} 1 ; \mathbf{0 3})$ & Minimum - Maximum \\
\hline Age & $14.3 \pm 2.2$ & $14.0(12.0 ; 16.0)$ & $11.0-18.0$ \\
\hline Age at menarche & $12.4 \pm 1.4$ & $12.0(11.0 ; 13.5)$ & $10.0-15.0$ \\
\hline $\begin{array}{c}\text { Age at diagnosis } \\
\text { of scoliosis }\end{array}$ & $11.9 \pm 1.3$ & $12.0(11.0 ; 13.0)$ & $9.0-14.0$ \\
\hline
\end{tabular}

Table 2. Distribution of the Cobb angle values by the curve analyzed and the radiographic incidence performed.

\begin{tabular}{|c|c|c|c|}
\hline Variables & Mean \pm SD & Median (01; Q3) & $\begin{array}{c}\text { Minimum - } \\
\text { Maximum }\end{array}$ \\
\hline $\begin{array}{l}\text { COBB proximal thoracic } \\
\text { (orthostatic AP) }\end{array}$ & $22.4 \pm 12.2$ & $21.0(14.5 ; 24.0)$ & $6.0-60.0$ \\
\hline $\begin{array}{l}\text { COBB main thoracic } \\
\text { (orthostatic AP) }\end{array}$ & $55.6 \pm 13.1$ & $56.0(50.0 ; 62.0)$ & $30.0-88.0$ \\
\hline $\begin{array}{l}\text { COBB thoracolumbar/lumbar } \\
\text { (orthostatic AP) }\end{array}$ & $40.1 \pm 13.1$ & $40.0(26.0 ; 50.0)$ & $20.0-65.0$ \\
\hline $\begin{array}{c}\text { COBB lateral T5-T12 } \\
\text { (orthostatic) }\end{array}$ & $25.9 \pm 11.8$ & $30.0(15.5 ; 34.5)$ & $6.0-50.0$ \\
\hline $\begin{array}{l}\text { COBB proximal thoracic } \\
\text { (supine inclination) }\end{array}$ & $20.0 \pm 12.2$ & $18.0(13.0 ; 24.5)$ & $6.0-50.0$ \\
\hline $\begin{array}{l}\text { COBB main thoracic } \\
\text { (supine inclination) }\end{array}$ & $30.5 \pm 12.4$ & $30.0(22.0 ; 36.0)$ & $12.0-57.0$ \\
\hline $\begin{array}{l}\text { COBB thoracolumbar/lumbar } \\
\text { (supine inclination) }\end{array}$ & $17.1 \pm 9.7$ & $20.0(8.0 ; 22.0)$ & $4.0-34.0$ \\
\hline $\begin{array}{l}\text { COBB proximal thoracic } \\
\text { (prone inclination) }\end{array}$ & $17.1 \pm 13.3$ & $14.0(9.0 ; 20.0)$ & $6.0-50.0$ \\
\hline $\begin{array}{l}\text { COBB main thoracic } \\
\text { (prone inclination) }\end{array}$ & $28.3 \pm 12.2$ & $26.0(20.0 ; 32.0)$ & $10.0-64.0$ \\
\hline $\begin{array}{l}\text { COBB thoracolumbar/lumbar } \\
\text { (prone inclination) }\end{array}$ & $16.7 \pm 8.4$ & $16.0(10.0 ; 20.0)$ & $6.0-34.0$ \\
\hline
\end{tabular}

Cobb angles were analyzed in the right and left lateral inclination radiographs in the prone position, the mean measurements for the proximal thoracic, main thoracic, and thoracolumbar/lumbar curves were $17.1^{\circ}$ $\pm 13.3^{\circ}, 28.3^{\circ} \pm 12.2^{\circ}$, and $16.7^{\circ} \pm 8.4^{\circ}$, respectively. (Table 2)

The mean flexibility rates measured, when considering the Cobb angle values of the curves in the right and left inclinations in supine and prone positions, are shown in Table 3.

The analysis of the difference between the flexibility rates of the scoliotic curves, considering the lateral inclinations with the patient in the supine and prone positions did not show any statistically significant difference between the positions analyzed. (Table 4)

Note: In Table 4 there is no statistically significant difference between the positions analyzed.

Table 5 shows the distribution of the patients by Lenke classification (from 1 to 6), when the lateral inclinations radiographs are considered in each decubitus position analyzed. We observed only one case in which the Lenke classification changed from type 1 in the supine position to type 2 in the prone position.

The correlation between the age at AIS diagnosis and the flexibility rate of the thoracolumbar/lumbar curve in the supine position was directly proportional and significant ( $p$-value $\leq 0.05$ ). The correlation between the proximal thoracic Cobb angle in orthostatic AP and the flexibility rate was inversely proportional, but there was a significant correlation only with flexibility rates of the proximal thoracic curve in the supine and prone positions. (Table 6)

When we correlated family history, vest use, and physical therapy with the flexibility rate of the curves in the prone and supine positions and the Cobb angle of the curves in orthostatic AP, there was a statistically significant difference only in vest use in relation to the rate of flexibility of the proximal thoracic curve in the supine position and in physical therapy in relation to the Cobb angle of the proximal thoracic curve in orthostatic AP. (Table 7)
Table 3. Distribution of the flexibility percentage values by curve analyzed and supine and prone patient positions.

\begin{tabular}{|c|c|c|c|}
\hline V & lean \pm SD & Median & $\begin{array}{l}\text { Minimum - } \\
\text { Maximum }\end{array}$ \\
\hline $\begin{array}{l}\% \mathrm{Fle} \\
\text { the }\end{array}$ & 3.8 & 45.5 (17. & $9.1-100.0$ \\
\hline $\begin{array}{r}\% \text { Flexibilit } \\
\mathrm{s} \\
\end{array}$ & 5.6 & 43.3 & 12.5 \\
\hline $\begin{array}{r}\% \text { Flexibility } \\
\text { lumb }\end{array}$ & 1 & 85.0160 & 4 \\
\hline $\begin{array}{r}\% \text { Flex } \\
\text { thor }\end{array}$ & 3 & 64.8 & $9.1-100.0$ \\
\hline $\begin{array}{c}\text { \% Flexibility main thoracic } \\
\text { prone }\end{array}$ & 2.8 & 50. & 21. \\
\hline $\begin{array}{r}\text { 10 Flexibility } \\
\text { lumba }\end{array}$ & $30.6 \pm 19.0$ & $80.0(65.0 ; 100.0)$ & $47.7-1$ \\
\hline
\end{tabular}

Table 4. Analysis of the difference between the rates of flexibility of the scoliotic curves considering the lateral inclinations with the patient in the supine or prone position.

\begin{tabular}{c|c|c|c}
\hline & \multicolumn{2}{|c|}{ Position } & \\
\hline Variables & Supine & Prone & p-value \\
\hline & Mean \pm SD & Mean \pm SD & \\
\hline \% Flexibility proximal thoracic & $54.4 \pm 38.8$ & $66.4 \pm 34.3$ & 0.107 \\
\hline \% Flexibility main thoracic & $45.8 \pm 15.6$ & $50.1 \pm 12.8$ & 0.309 \\
\hline \% Flexibility thoracolumbar/lumbar & $80.5 \pm 20.7$ & $80.6 \pm 19.0$ & 1.000 \\
\hline$\left.{ }^{\star}\right)$ Wilcoxon test.
\end{tabular}

Table 5. Absolute and percent distribution of the Lenke classification when lateral inclination radiographs in the supine and prone positions were considered.

\begin{tabular}{c|c|c}
\hline Variables & $\mathbf{n}$ & \% \\
\hline Lenke classification supine & & 78.9 \\
\hline Type 1 & 15 & 10.5 \\
\hline Type 2 & 2 & 5.3 \\
\hline Type 3 & 1 & 5.3 \\
\hline Type 5 & 1 & \\
\hline Lenke classification prone & & 84.1 \\
\hline Type 1 & 16 & 5.3 \\
\hline Type 2 & 1 & 5.3 \\
\hline Type 3 & 1 & 5.3
\end{tabular}

Table 6. Correlation between the flexibility rates of the curves in prone and supine positions and between age and the Cobb angle of the curve in orthostatic AP.

\begin{tabular}{c|c|c|c|c}
\hline Variables A $^{\text {A }}$ & $\begin{array}{c}\text { Age when } \\
\text { scoliosis was } \\
\text { discovered }\end{array}$ & $\begin{array}{c}\text { Proximal } \\
\text { thoracic Cobb } \\
\text { (orthostatic } \\
\text { AP) }\end{array}$ & $\begin{array}{c}\text { Main thoracic } \\
\text { Cobb } \\
\text { (orthostatic } \\
\text { AP) }\end{array}$ & $\begin{array}{c}\text { Thoracolumbar } \\
\text { / lumbar } \\
\text { (orthostatic } \\
\text { AP) }\end{array}$ \\
\hline $\begin{array}{c}\% \text { Flexibility } \\
\text { proximal } \\
\text { thoracic supine }\end{array}$ & 0.290 & $-0.542^{*}$ & -0.431 & -0.177 \\
\hline $\begin{array}{c}\% \text { Flexibility } \\
\text { main thoracic } \\
\text { supine }\end{array}$ & 0.201 & -0.107 & -0.097 & -0.275 \\
\hline $\begin{array}{c}\% \text { Flexibility } \\
\text { thoracolumbar/ } \\
\text { lumbar supine }\end{array}$ & $0.475^{*}$ & 0.090 & -0.106 & $-0.851^{*}$ \\
\hline $\begin{array}{c}\% \text { Flexibility } \\
\text { proximal } \\
\text { thoracic prone }\end{array}$ & 0.405 & $-0.595 *$ & $-0.660 *$ & -0.284 \\
\hline $\begin{array}{c}\% \text { Flexibility } \\
\text { main thoracic } \\
\text { prone }\end{array}$ & 0.231 & -0.103 & -0.236 & 0.065 \\
\hline $\begin{array}{c}\% \text { Flexibility } \\
\text { thoracolumbar/ } \\
\text { lumbar prone }\end{array}$ & 0.340 & 0.019 & -0.003 & $-0.804^{*}$ \\
\hline
\end{tabular}

(A) Spearman's correlation $\left(^{*}\right)$ Significant correlation ( $p$-value $\left.\leq 0.05\right)$. 
Table 7. Correlation between family history, vest use, and physical therapy with the flexibility rates of the curves in the prone and supine positions and the Cobb angle of the curves in orthostatic AP.

\begin{tabular}{c|c|c|c|c|c|c|c|c|c}
\hline & \multicolumn{2}{|c|}{$\%$ Flexibility Supine } & \multicolumn{2}{c|}{$\%$ Flexibility Prone } & \multicolumn{3}{c}{ Cobb (orthostatic AP) } \\
\hline Variables & $\begin{array}{c}\text { Proximal } \\
\text { thoracic }\end{array}$ & Main thoracic & $\begin{array}{c}\text { Thoracolumbar } \\
\text { lumbar }\end{array}$ & $\begin{array}{c}\text { Proximal } \\
\text { thoracic }\end{array}$ & Main thoracic & $\begin{array}{c}\text { Thoracolumbar } \\
\text { lumbar }\end{array}$ & $\begin{array}{c}\text { Proximal } \\
\text { thoracic }\end{array}$ & $\begin{array}{c}\text { Main thoracic } \\
\text { Thoracolumbar } \\
\text { lumbar }\end{array}$ \\
\hline & Mean \pm SD & Mean \pm SD & Mean \pm SD & Mean \pm SD & Mean \pm SD & Mean \pm SD & Mean \pm SD & Mean \pm SD & Mean \pm SD \\
\hline Vest use & & & & & & & & & \\
\hline Yes & $16.1 \pm 4.9$ & $34.2 \pm 15.5$ & $79.1 \pm 24.8$ & $54.1 \pm 33.8$ & $54.7 \pm 19.5$ & $79.7 \pm 23.0$ & $24.5 \pm 5.3$ & $54.7 \pm 14.0$ & $43.3 \pm 9.8$ \\
\hline No & $67.2 \pm 36.5$ & $51.1 \pm 13.0$ & $81.2 \pm 19.6$ & $70.5 \pm 35.0$ & $48.0 \pm 8.6$ & $81.0 \pm 18.0$ & $21.8 \pm 13.9$ & $56.0 \pm 13.2$ & $38.6 \pm 14.5$ \\
\hline p-value ${ }^{*}$ & 0.021 & 0.053 & 0.927 & 0.486 & 0.660 & 0.927 & 0.223 & 0.824 & 0.289 \\
\hline Physical therapy & & & & & & & & \\
\hline Yes & $78.1 \pm 43.8$ & $48.7 \pm 15.6$ & $75.6 \pm 23.0$ & $87.5 \pm 25.0$ & $49.0 \pm 1.2$ & $79.0 \pm 16.4$ & $13.0 \pm 4.8$ & $49.0 \pm 9.9$ & $40.5 \pm 8.2$ \\
\hline No & $46.6 \pm 35.4$ & $45.0 \pm 16.1$ & $81.9 \pm 20.7$ & $59.4 \pm 35.0$ & $50.4 \pm 14.5$ & $81.0 \pm 20.2$ & $25.6 \pm 12.4$ & $57.3 \pm 13.5$ & $40.0 \pm 14.4$ \\
\hline p-value ${ }^{*}$ & 0.290 & 0.841 & 0.533 & 0.163 & 0.920 & 0.835 & 0.024 & 0.188 & 0.920 \\
\hline Family history & & & & & & & & \\
\hline Yes & $29.3 \pm 21.9$ & $41.7 \pm 23.6$ & $86.9 \pm 26.2$ & $37.6 \pm 19.3$ & $44.5 \pm 8.9$ & $86.9 \pm 26.2$ & $35.3 \pm 21.4$ & $55.0 \pm 10.5$ & $37.8 \pm 20.5$ \\
\hline No & $60.3 \pm 40.1$ & $46.9 \pm 13.7$ & $78.8 \pm 19.8$ & $73.1 \pm 34.0$ & $51.6 \pm 13.6$ & $78.9 \pm 17.5$ & $19.5 \pm 7.7$ & $55.7 \pm 14.0$ & $40.7 \pm 11.3$ \\
\hline p-value ${ }^{*}$ & 0.189 & 0.764 & 0.377 & 0.122 & 0.366 & 0.436 & 0.079 & 0.800 & 0.615
\end{tabular}

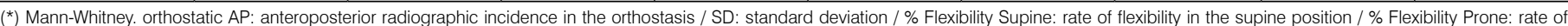

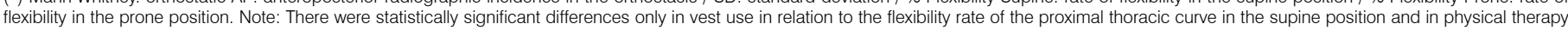
in relation to the Cobb angle of the proximal thoracic curve in orthostatic AP.

\section{DISCUSSION}

The evaluation of AIS involves a directed medical history, a detailed physical examination, and a full-spine radiological assessment, evaluating the magnitude and flexibility of the curves. This study observed an age distribution of AIS like that described in other studies. The mean age of the patients included in the study was 14.3 years, with a mean age at diagnosis of 11.9 years. ${ }^{2,12-14}$ The mean Cobb angle values reported in this study for the proximal thoracic and main thoracic curves in the orthostatic position $\left(22.4^{\circ}\right.$ and $55.6^{\circ}$, respectively) approximate what Klepps et al. described in 2001 (19 for the proximal thoracic and $58^{\circ}$ for the main thoracic curve). ${ }^{15}$

Several classifications have been published in order to assist the evaluation of curves and the therapeutic indication. Currently, the Lenke classification is widely used and helps the spine surgeon in preoperative planning for adolescent idiopathic scoliosis. It defines the criteria for determining the structure of the minor scoliotic curves (reducing the Cobb angle to $25^{\circ}$ or more in the lateral inclination radiographs or the kyphosis angle $>20^{\circ}$ ), providing the physician with support for inclusion of these curves in surgical planning, avoiding extensive or insufficient arthrodesis in the treatment of AIS. ${ }^{10}$

The radiographic method to be used in patients with AIS for the classification, the assessment of flexibility and structure of the minor curve (for example: the traction, the lateral inclination in dorsal decubitus, the lateral inclination in ventral decubitus, among others) is discussed extensively in the literature. ${ }^{16-20}$ As an example, we cite the comparison between the flexibility of AIS curves using EOS and lateral inclination radiographs in the supine position, where no statistically significant differences in the reducibility of the Cobb angle were reported. ${ }^{21}$ In another study, the use of traction radiographs to assess the flexibility of AIS curves was shown to be comparable to using lateral inclination radiographs in the supine position. ${ }^{13} \mathrm{Ano}-$ ther method described in the literature that has been shown to be reproducible is the use of radiographs in the supine position, which can replace two lateral inclination radiographs with a single image. ${ }^{8}$ Lamarre et al., in turn, compared lateral inclination and suspension radiographs, showing that suspension radiographs are viable in the evaluation of the flexibility of AIS curves. ${ }^{17}$ Another study, developed by Bekki et al., evaluated the use of prone and supine position radiographs to determine which was better in the evaluation of AIS curve flexibility. They evaluated 32 patients, 26 female and 6 male, and observed that the supine position radiographs were adequate for evaluating the flexibility of AIS curves, especially type C lumbar curves. $^{6}$

We observed a direct relationship between the Cobb angle of the proximal thoracic curve in the anteroposterior incidence radiograph in orthostasis and the flexibility of the proximal curve in the prone and supine positions. The thoracolumbar/lumbar Cobb angle in an orthostatic AP had a direct relationship with the rates of flexibility of the thoracolumbar/lumbar curves in prone and supine decubitus. Therefore, this suggests that a greater Cobb angle is related to the structure of smaller curves in AIS, agreeing with what is shown in the literature..$^{22,23}$

The data obtained also showed a change in the Lenke classification in only one of the 19 patients analyzed (Lenke 2 with supine decubitus and Lenke 1 with prone decubitus). The flexibility rates measured considering lateral inclination in the supine position, in turn, have values close to those reported by Klepps et al. for the main thoracic curves, corroborating the results of our study. ${ }^{19}$ The assessment of the flexibility rates of the curves in the prone and supine inclination radiographs in this study did not reveal any statistically significant difference in the flexibility rates of the curves, suggesting that the two radiographic methods analyzed are similar in this evaluation. (Table 6). Similar results have been reported in the literature, observing no statistically significant differences in the evaluation of the flexibility of the curves in prone and supine position radiographs. ${ }^{6}$

Our results are also like those of other studies involving comparisons between different techniques for measuring the flexibility of idiopathic scoliosis curves that do not report any superiority between the different techniques assessed. ${ }^{12,18,19,21}$

\section{CONCLUSION}

This study found no statistically significant difference between the flexibility rates of the curves in prone and supine positions, suggesting that the two radiographical methods analyzed are similar in their evaluation of the curves in adolescent idiopathic scoliosis.

All authors declare no potential conflict of interest related to this article. 
CONTRIBUTION OF THE AUTHORS: Each author made significant individual contributions to this manuscript. MPMS, AFFP, TAMR, RCM, LTBC, MACF, and ARSF: writing, revision, data collection, statistical analysis, preparation of research project.

\section{REFERENCES}

1. Hattori T, Sakaura H, Iwasaki M, Nagamoto Y, Yoshikawa H, Sugamoto K. In vivo three-dimensional segmental analysis of adolescent idiopathic scoliosis. Eur Spine J. 2011:20(10):1745-50.

2. Weinstein SL, Dolan LA, Cheng JCY, Danielsson A, Morcuende JA. Adolescent idiopathic scoliosis. Lancet. 2008:371:1527-37.

3. Agabegi SS, Kazemi N, Sturm PF, Mehlman CT. Natural History of Adolescent Idiopathic Scoliosis in Skeletally Mature Patients: A Critical Review. J Am Acad Orthop Surg. 2015;23(12):714-23.

4. Lo YF, Huang YC. [Bracing in Adolescent Idiopathic Scoliosis]. Hu Li Za Zhi. 2017;64(2):117-23.

5. Cheng JC, Castelein RM, Chu WC, Danielsson AJ, Dobbs MB, Grivas TB, et al. Adolescent idiopathic scoliosis. Nature Reviews Disease Primers. 2015;1:15030.

6. Bekki H, Harimaya K, Matsumoto Y, Kawaguchi K, Hayashida M, Okada S, et al. Which Side-Bending X-ray Position is Better to Evaluate the Preoperative Curve Flexibility in Adolescent Idiopathic Scoliosis Patients, Supine or Prone? Asian Spine J. 2018;12(4):632-8.

7. Hirsch C, Ilharreborde B, Mazda K. Flexibility analysis in adolescent idiopathic scoliosis on side-bending images using the EOS imaging system. Orthop Traumatol Surg Res. 2016;102(4):495-500.

8. Cheh G, Lenke LG, Lehman Jr RA, Kim YJ, Nunley R, Bridwell KH. The reliability of preoperative supine radiographs to predict the amount of curve flexibility in adolescent idiopathic scoliosis. Spine (Phila Pa 1976). 2007:32(24):2668-72.

9. King HA, Moe JH, Bradford DS, Winter RB. The selection of fusion levels in thoracic idiopathic scoliosis. J Bone Joint Surg Am. 1983;65(9):1302-13.

10. Lenke LG, Betz RR, Harms J, Bridwell KH, Clements DH, Lowe TG, et al. Adolescent idiopathic scoliosis: a new classification to determine extent of spinal arthrodesis. J Bone Joint Surg Am. 2001;83(8):1169-81.

11. Little JP, Adam CJ. The effect of soft tissue properties on spinal flexibility in scoliosis: biomechanical simulation of fulcrum bending. Spine (Phila Pa 1976). 2009;34(2):E76-82.

12. Zheng Y, Dang Y, Wu X, Yang Y, Reinhardt JD, He C, et al. Epidemiological study of adolescent idiopathic scoliosis in eastern China. J Rehabil Med. 2017;49(6):512-9.
13. Hengwei $F$, Zifang $H$, Qifei W, Weiqing $T$, Nali $D$, Ping $Y$, et al. Prevalence of Idiopathic Scoliosis in Chinese Schoolchildren: A Large, Population-Based Study. Spine (Phila Pa 1976). 2016;41(3):259-64.

14. Wren TAL, Ponrartana S, Poorghasamians E, Moreau S, Aggabao PC, Zaslow TL, et al. Biomechanical Modeling of Spine Flexibility and Its Relationship to Spinal Range of Motion and Idiopathic Scoliosis. Spine Deform. 2017;5(4):225-30.

15. Klepps SJ, Lenke LG, Bridwell KH, Bassett GS, Whorton J. Prospective Comparison of Flexibility Radiographs in Adolescent Idiopathic Scoliosis. Spine (Phila Pa 1976). 2001;26(5):E74-9

16. He C, Wong MS. Spinal flexibility assessment on the patients with adolescent idiopathic scoliosis (AIS): a literature review. Spine (Phila Pa 1976). 2018;43(4):E250-8.

17. Lamarre ME, Parent S, Labelle H, Aubin CE, Joncas J, Cabral A, et al. Assessment of spinal flexibility in adolescent idiopathic scoliosis: suspension versus side-bending radiography. Spine (Phila Pa 1976). 2009;34(6):591-7

18. Fei Q, Wang YP, Qiu GX, Zhao Y, Shen JX, Zhang JG, et al. Assessment of curve flexibility in adolescent idiopathic scoliosis before operation. Zhonghua Yi Xue Za Zhi. 2007:87(35):2484-8.

19. Li J, Hwang S, Wang F, Chen Z, Wu H, Li B, et al. An innovative fulcrum-bending radiographical technique to assess curve flexibility in patients with adolescent idiopathic scoliosis. Spine (Phila Pa 1976). 2013;38(24):E1527-32

20. Liu RW, Teng AL, Armstrong DG, Poe-Kochert C, Son-Hing JP, Thompson GH. Comparison of supine bending, push-prone, and traction under general anesthesia radiographs in predicting curve flexibility and postoperative correction in adolescent idiopathic scoliosis. Spine (Phila Pa 1976). 2010;35(4):416-22.

21. Khodaei M, Pachêco-Pereira C, Trac S, Chan A, Le LH, Lou E. Radiographic Methods to Estimate Surgical Outcomes based on Spinal Flexibility Assessment in Patients who have Adolescent Idiopathic Scoliosis: A Systematic Review. Spine J. 2018;18(11):2128-39.

22. Clamp JA, Andrews JR, Grevitt MP. A study of the radiologic predictors of curve flexibility in adolescent idiopathic scoliosis. J Spinal Disord Tech. 2008;21(3):213-5.

23. Deviren V, Berven S, Kleinstueck F, Antinnes J, Smith JA, Hu SS. Predictors of flexibility and pain patterns in thoracolumbar and lumbar idiopathic scoliosis. Spine (Phila Pa 1976). 2002;27(21):2346-9. 